\title{
Mariusz Sangórski
}

Wroclaw University of Economics and Business, Poland e-mail: mariusz.sangorski@ue.wroc.pl

ORCID: 0000-0001-56493-9816

\section{Arkadiusz Wierzbic}

Wroclaw University of Economics and Business, Poland e-mail: arkadiusz.wierzbic@ue.wroc.pl

ORCID: 0000-0003-0118-4123

USING COMPUTER SOFTWARE FOR ENERGY SAVING DETERMINATION IN COMPLEX BUSINESS PROCESSES - A CASE STUDY OF KGHM POLSKA MIEDŹ S.A.

WYKORZYSTANIE OPROGRAMOWANIA

KOMPUTEROWEGO W CELU OKREŚLENIA

OSZCZĘDNOŚCI ENERGII W ZLOŻONYCH

PROCESACH BIZNESOWYCH NA PRZYKLADZIE KGHM POLSKA MIEDŹ SA

DOI: $10.15611 /$ ie.2020.4.09

JEL Classification: C25, C44, C88, D81, L86

(a) 2020 Mariusz Sangórski, Arkadiusz Wierzbic

This work is licensed under the Creative Commons Attribution-ShareAlike 4.0 International License. To view a copy of this license, visit http://creativecommons.org/licenses/by-sa/4.0/

Quote as: Sangórski, M., \& Wierzbic, A. (2020). Using computer software for energy saving determination in complex business processes - a case study of KGHM Polska Miedź S.A. Informatyka Ekonomiczna. Business Informatics, (4).

\footnotetext{
Abstract: The improvement of energy efficiency, which is the desired effect of pro-efficiency measures, is defined by determining the amount of energy savings as the impact of the effectively realised actions. Properly defined energy savings are the essential management information that, correctly used, can increase the value of the company as the knowledge about the effects of the decisions made. The proper definition of saving requires understanding of what it is because, without it, there is no chance for its correct determination, which makes the whole work worthless. The article aims to present the method used in KGHM Polska Miedź S.A. of properly implementing energy savings and the computer software used for this purpose. The method is based on the statistical modelling of energy use supported by a tool initially used for statistical process control. The described method applies not only to individual pro-efficiency activities or simple technological processes, but also to complex
} 
business processes, and the software is easy to use and in the described version, free of charge. The implementation of the described solution enables obtaining high-quality management information quickly and at a moderate cost.

Keywords: ISO 50001, EnMS, energy savings, statistic modelling, energy performance.

Streszczenie: Poprawę efektywności energetycznej, będącą pożądanym efektem działań proefektywnościowych, stwierdza się, określając wielkość uzyskanej dzięki tym działaniom oszczędności energii. Prawidłowo określona oszczędność energii jest kluczową informacją zarządczą, której odpowiednie wykorzystanie pozwala podnosić wartość przedsiębiorstwa dzięki wiedzy o efektach podjętych decyzji. Właściwe określenie oszczędności wymaga zrozumienia, czym ona jest, bez tego bowiem nie ma mowy o jej prawidłowym wyznaczeniu, co czyni jej określanie bezwartościowym. Celem artykułu jest zaprezentowanie wykorzystywanej w KGHM Polska Miedź SA metody prawidłowego wyznaczania oszczędności energii i używanego w tym celu programu komputerowego. Metoda bazuje na modelowaniu statystycznym zużycia energii wspieranym narzędziem pierwotnie wykorzystywanym do statystycznej kontroli procesów. Opisana metoda ma zastosowanie nie tylko do pojedynczych działań proefektywnościowych czy prostych procesów technologicznych, ale i do złożonych procesów biznesowych, wykorzystywany program jest łatwy zaś w użyciu i w opisywanej wersji bezpłatny. Wdrożenie opisywanego rozwiązania umożliwia uzyskanie wysokiej jakości informacji zarządczej szybko i umiarkowanym kosztem.

Słowa kluczowe: ISO 50001, oszczędność energii, modelowanie statystyczne, efektywność energetyczna.

\section{Introduction}

The European Union is dependent on energy imports. In 2018 the EU countries imported over half (58.2\%) of the consumed energy (Eurostat, 2020). This situation is not optimal and even dangerous for the EU's energy security, hence the Energy Union was established, which developed a strategy to provide consumers with safe and competitive access to sustainably produced energy (European Commission, 2015). The plan sets out measures to increase energy security, stability and competitiveness in the EU by reducing the demand for energy and energy consumption. The way to achieve these goals is to improve the broadly understood energy efficiency of energy-consuming processes. To do this, the Directive of the European Parliament and the EU Council on energy efficiency specifies the obligation for EU member states to take actions aimed at achieving specific energy savings in the period 2021-2030 (Directive (EU), 2018). This obligation, concerning the period 2014-2020, was earlier defined in the Directive of the European Parliament and the EU Council on energy efficiency (Directive (EU), 2012). Based on this Directive, the Poland undertook to fulfil it in part by establishing the Energy Efficiency Act (Ustawa..., 2016). The EU recommendation, defined in 2019, transposed the obligation to achieve savings specified in the Directive (Directive (EU), 2018) to the EU Member States (Commission Recommendation (EU), 2019). 
This obligation has to be fulfilled by pro-efficiency actions that should be taken when the national executive act (Energy Efficiency Act) will be actualised.

The companies covered by the obligation regularly undertake many proefficiency measures, however the fundamental technical problem is to determine the amount of savings achieved by them. This problem can be broken down into two issues:

- How to record the savings reached concerning the planned savings?

- How to define actual energy savings - in the meaning specified in the Directive (Directive (EU), 2018)?

The answer to the first question is simple - the savings are estimated and then measured concerning a precisely defined business, technological or process area. The answer to the second question requires understanding the concept of 'saving' and conducting a complex analysis. Without IT support this task is very laborious.

The purpose of this article is to present how the use of commonly available software (MS Excel and RETScreen) can solve a defined problem relatively quickly and with moderate effort. The way in which the issue is presented is clarifying the term 'energy saving' and then showing the process of data analysis leading to the establishment of energy saving and preparing information valuable in the management process.

\section{Process of energy consumption data analysis}

\subsection{Energy saving}

The term energy saving is defined as "an amount of saved energy determined by measuring and/or estimating consumption before and after implementation of an energy efficiency improvement measure, whilst ensuring normalisation for external conditions that affect energy consumption" (Directive (EU), 2012, art.2.5). This approach is reflected in the international standards where the energy-saving is defined as "the reduction of energy consumption following implementation of an energy performance improvement action" (ISO/IEC 13273-1, 2015, 3.3.9) or by specifying the method of its determination: "the reduction of energy consumption compared to an energy baseline" (ISO 17743, 2016, 3.8) with the note "Energy savings may be the result of the implementation of an action(s)". The critical issue in the proper determining of the energy saving is correctly designating "the energy baseline" that is defined as "the quantitative reference(s) providing a basis for a comparison of energy performance" (ISO 17741, 2016, 3.4; ISO 50001, 2018, 3.4.7; ISO 50046, 2019, 3.6).

To fully understand what "energy saving" is and how to determine it, the above definitions can be used to create one complex and consistent with them as follows:

"Energy saving is the reduction of energy consumption, following the implementation of energy performance improvement activities. Energy saving is 
determined by comparing energy consumption measured after the implementation of the improvement activities to the energy baseline. The energy baseline is the estimated energy that would be consumed if the improvement activities had not been implemented. Energy consumption is measured and estimated in the same conditions".

This definition means that the comparisons of measured and estimated energy consumption have to be done in the same standard period.

In most cases energy saving is understood intuitively as the simple difference between energy consumption in two, usually consecutive periods of the same duration. That approach works well in simple cases, related to the short-lived replacement of energy-intensive equipment with the energy-saving one. This approach, based on comparing energy consumption in different periods, is suggested in European standards (e.g. EN 16212, 2012; EN 16247, 2012), international standards (e.g. ISO 17741, 2016; ISO 17743, 2016; ISO 50001, 2018; ISO 50006, 2015; ISO 50047, 2016) and in many guides (such as: BMU, 2012; Cosenza et al., 2018; Howell, 2014; Lycken, Nilsson, Olsson, Diederichs, Welling, \& Guennec, 2015; UNIDO, 2015). It works well when conditions affecting energy consumption do not change in the considered periods. However, if they do change, the effect of the determination of energy saving can be dramatically incorrect, leading to a completely wrong decision. In the case of complex business processes, which integrates numerous sub-processes, the simplified approach will give the appropriate result only by chance.

Energy consumption is quantitative information, only answering the question "how much?" and not any other, such as "is that good?". On having quantitative information, the managers can then decide to obtain more significant, the same or lesser energy consumption, but they will never know if that decision led to improving energy management.

The achieved energy saving is the qualitative information that answers the question "how good is it" - is it good, acceptable or poor? The manager who is looking for advice to assess whether the decision was right in improving energy management, must rely on qualitative information. This issue makes determining appropriate energy-saving crucial for effective managing.

The task of the appropriate determining of energy saving on any requested organisational and business level can be done in Microsoft Excel. In KGHM, Microsoft Excel and the RETScreen Plus are used to make all the process more convenient to conduct. RETScreen Plus is a data analysis software used in the data analysis process and is described in the next chapter.

\subsection{Energy saving determine software}

Nowadays in the market, there is a wide choice of energy management software (EMS) - see Table 1. 
Table 1. Examples of Energy Management Software

\begin{tabular}{|l|l|}
\hline \multicolumn{1}{|c|}{ Software by developer } & \multicolumn{1}{c|}{ Website } \\
\hline $\begin{array}{l}\text { The EnergyCAP Software Solution } \\
\text { by EnergyCAP, Inc. }\end{array}$ & https://www.energycap.com/software \\
\hline EcoStruxure Power by Shneider Electric & $\begin{array}{l}\text { https://www.se.com/us/en/work/solutions/power-and-e- } \\
\text { nergy-management-solutions/ }\end{array}$ \\
\hline eSight ${ }^{\circ}$ Software by Esightenergy & https://www.esightenergy.com/ \\
\hline HARA-Vx Observe by Accruent & $\begin{array}{l}\text { https://www.accruent.com/solutions/energy-sustainabili- } \\
\text { ty-management/energy-management-vs-observe }\end{array}$ \\
\hline $\begin{array}{l}\text { Siemens' Energy Efficiency Analytics } \\
\text { (EEA) by Siemens }\end{array}$ & $\begin{array}{l}\text { https://new.siemens.com/global/ren/products/energy/ } \\
\text { energy-automation-and-smart-grid/grid-edge-software/ } \\
\text { eea.html }\end{array}$ \\
\hline Wattics by Wattics & http://www.wattics.com/ \\
\hline $\begin{array}{l}\text { Entronix Energy Management Platform } \\
\text { by Entronics }\end{array}$ & http://entronix.io \\
\hline Eniscope by Best.Energy & https://bestenergy/ \\
\hline Portal by Emaze & http://www.eportal.eu/en/ \\
\hline Energis. Cloud by Energis SA/NV & $\begin{array}{l}\text { https://communication.energis.cloud/energis-cloud-mo- } \\
\text { nitor-and-optimise-energy-performance-thermal-comfor- } \\
\mathrm{t}-0 \text { ?utmchannel=capterra }\end{array}$ \\
\hline Energy Elephant by Energy Elephant Ltd. & $\begin{array}{l}\text { https://energyelephant.com/?capterra_utm_source=cap- } \\
\text { terra }\end{array}$ \\
\hline $\begin{array}{l}\text { etap by Electrical Power System Analysis } \\
\text { \& Operation Software }\end{array}$ & $\begin{array}{l}\text { https://etap.com/packages/energymanagemen- } \\
\text { t-system?httpsetapcomdemo-dow=capterra }\end{array}$ \\
\hline DEXMA by DEXMA & $\begin{array}{l}\text { https://get.dexma.com/the-fastest-growing-energy-mana- } \\
\text { gement-software-in-the-market?directory=capterra }\end{array}$ \\
\hline $\begin{array}{l}\text { EnergyLogicIQ by LogicLadder } \\
\text { Technologies }\end{array}$ & http://www.logicladder.com/ \\
\hline
\end{tabular}

Source: own study.

That software (and similar ones) has many functions. It can collect data (often with SCADA functionalities), effectively use the data (to monitor, target and reduce energy consumption), identify energy-saving potential, deliver actionable information (to plan the actions and projects) and much more. The software provides a complex solution for comprehensive energy management, it does not require clients to have knowledge about energy management, and it is expensive. Those users who have adequate knowledge and skills look for easy to use and cheap tools to support them in one task: determining the achieved energy saving. The paper presents the method of how to achieve this.

\subsection{Data analysis process placed in KGHM}

The purpose of the data analysis process is to deliver value in decision process information based on facts. The workflow of the process is depicted in Fig. 1. 


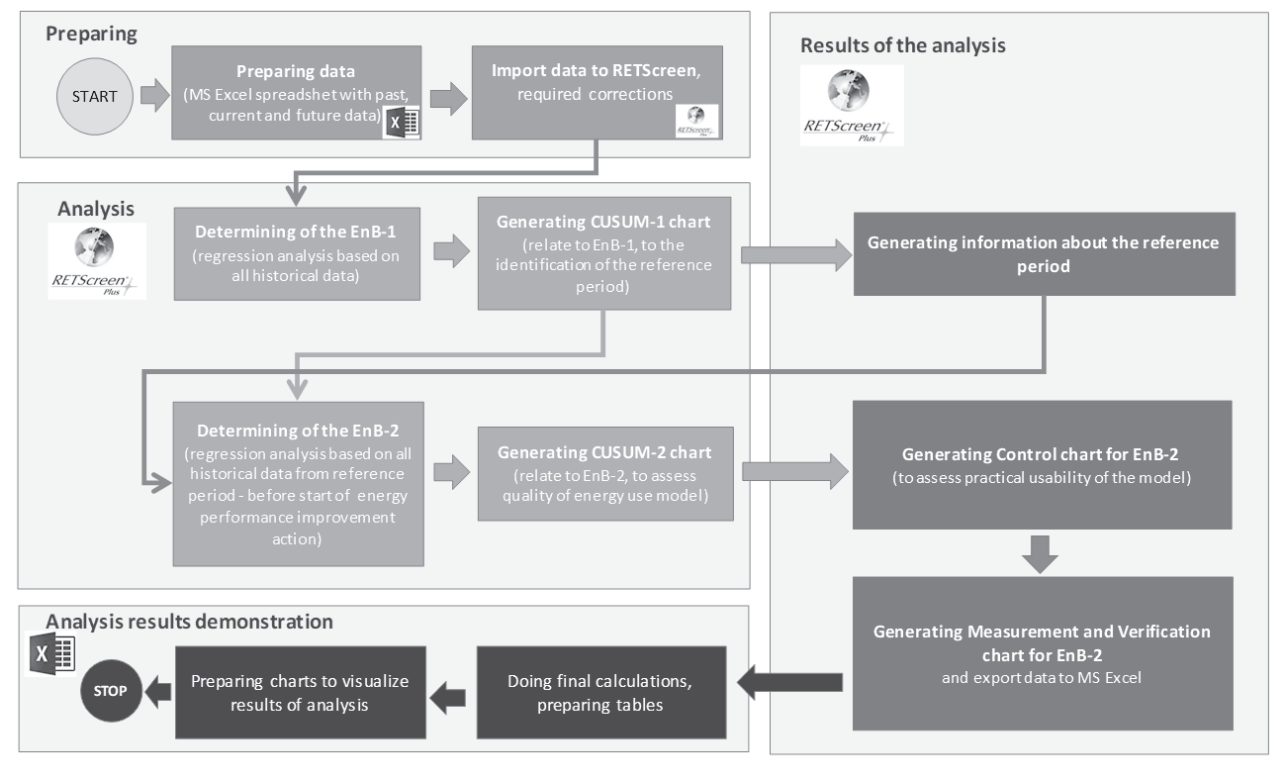

Fig. 1. Data analysis workflow

Source: own study.

During the preparation stage, the raw data (from SCADA or ERP systems) are imported to MS Excel in order for them to meet the RETScreen input data specification. The next step is importing data to RETScreen and making the necessary corrections of the data.

The second stage, analysis, begin with the creating the energy-use model based on all historical data using the multiple regression method (IPMVP, 2012; Syska, 2014). The analytical representation of the model is an equation one can use to generate the first energy baseline (EnB-1). The practical usefulness of the first energy use model is indefinite. The created model assesses with use of the CUSUM methodology (Greber, 2005), to confirm a known or find an unknown reference period that reflects the laminar process sequence.

After identifying the reference period, the study created the reference energy-use model to develop the second energy baseline (EnB-2). If the quality of the reference energy use model is adequate, which means it is usable in practice, one can deliver the correct energy baseline and the standard error of estimation. The thus created EnB-2 data are exported to MS Excel to make the final calculation of energy saving. In this stage, the tables and charts are created for the purpose of presenting the results of analysis in an unequivocal way, easy to understand and use. 


\subsection{Validation of the energy use model}

The energy-saving determining process will produce an appropriate result only if the reference period is found, what is not easy in complex business processes. The reference period was the time range when the analysed process was undisturbed, free from episodes related to the occurrence of one of a kind, unusual circumstances (as e.g. the replacement of the energy-intensive equipment with the energy-saving one). The evaluation of whether the found period is the reference, was judged with five evaluation criteria: two quantitative, based on regression results, and three qualitative, based on the CUSUM chart.

The first quantitative criterion is the coefficient of multiple determination (R-squared, $\mathrm{R}^{2}$ ) which reflects the quality of the variables match in a linear regression model (Cheng, Shalabh, \& Garg, 2012) showing how much (in \%) the independent variables are responsible for the variability of the dependent variable. It is essential to be aware that the R-squared coefficient describes the level of covariance not a cause and effect relationship, which need to be evaluated as a separate activity.

The second quantitative criterion is the standard error of the estimate. The study used it to evaluate subsequent iterations of the energy use model to find the one with the relatively minimal error.

The qualitative evaluation take place on the subjective expert's assessment of the cumulative sum (CUSUM) chart "which plots the cumulative sums of deviations of the sample values of a quality" (Koshti, 2011). The CUSUM chart can help detect a disturbance in the process by aggregating small continuous shifts of the process parameter between the real and predicted values as described in (Farkas, 2016; Lin Keogh, \& Lonardi, 2005; Świecicki \& Tautkut e, 2012). To evaluate if the energy use model was built on the reference period, three qualitative criteria were used:

a) minimal (best option: none) variability of the process,

b) minimal (best choice: none) alternating of the process,

c) the same trend CUSUM chart in the reference and the reporting period.

The creation process of the reference energy use model is iterative, so an easy to use supporting tool is vital to minimise the labour intensity of this task.

\section{Software used in the energy-saving determining process}

\subsection{RETScreen ${ }^{\circledR}$ software}

RETScreen ${ }^{\circledR}$ is the application used from 1998 by the Ministry of Natural Resources of Canada to create and validate clean energy projects (Government of Canada, 2020). It is a decision support tool designed to make complex economic and environmental assessment projects aimed at acquiring renewable energy or improving the broadly understood energy efficiency.

Currently the software is available in 36 languages, has over 675 thousand registered users and its use helped to save over 8 billion USD by 2016 (Copenhagen 
Centre of Energy Efficiency, 2020; Open Energy Information, 2020). The significant advantage of this software, apart from the relative ease of use, is that up to version 5.0 it was made available free of charge. Nowadays the officially available version of RETScreen Expert is available free of charge only in the 'viewer mode' version, but its functionality, compared to the free versions, has significantly increased. For the tasks realised in KGHM, the older version of RETScreen Plus is used as sufficient to perform the changes faced by those involved in the preparation of management information.

\subsection{RETScreen main functionality}

The primary functions of RETScreen Plus are illustrated in Figure 2 (Natural Resources Canada, 2005).

\section{Five Step Standard Analysis $\Theta$}
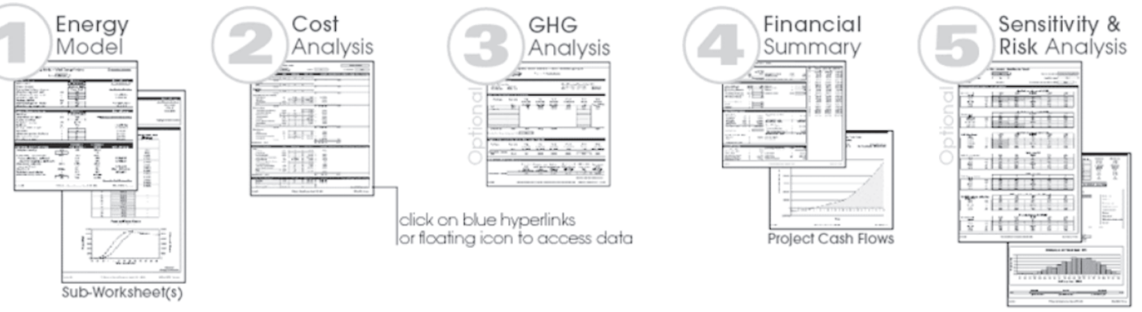

$\oplus$ Ready to make a decision
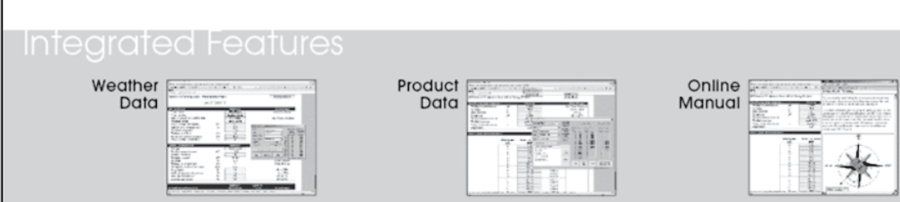

- Iraining Course

- Engineering Textbook

- Case Studies

- Online Marketplace

- Internet Forums

Fig. 2. Functional model of RETScreen software

Source: RETScreen ${ }^{\circledR}$ Software Online User Manual (NRC, 2005).

The first module (Energy Model) allows to build an energy use model, which is used to determine the amount of achievable savings resulting from the project implementation, that is the subject of the analysis performed in RETScreen.

The second module (Cost Analysis) enables the preparation of an economic assessment of the project.

The third module ( $G H G$ Analysis) enables an analysis of the profitability of a project from the perspective of reducing greenhouse gas emissions, which should be a natural consequence of the implementation of the project under consideration. 
The fourth module (Financial Summary) presents the complete set of financial information required for the business assessment of the profitability of the project.

The fifth module (Sensitivity \& Risk Analysis) makes it possible to conduct a risk and sensitivity analysis of the profitability of a project in response to the considered variability of the factors determining its profitability.

The RETScreen software also includes an online user manual and two additional modules supporting the process of evaluating a pro-efficiency project:

- a module for downloading weather data necessary for some analysis,

- a module containing editable data of elements and devices available on the market, used in pro-efficiency projects.

\subsection{RETScreen functionality used in the energy-saving determining process}

The software functionality used in KGHM Polska Miedź S.A. is a module for energy use modelling (Energy Model). The workflow carried out in this module as part of the process of determining energy savings is demonstrated in Figure 3.

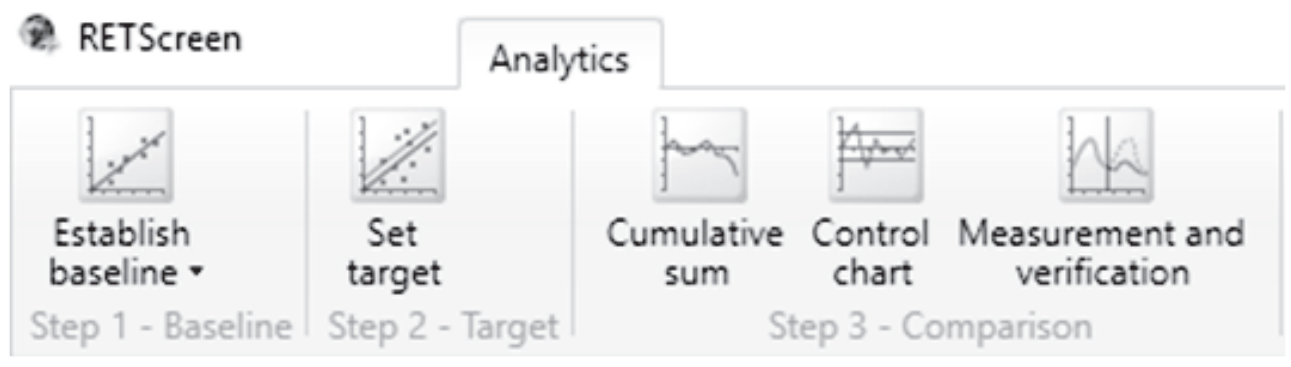

Fig. 3. The workflow in the Energy Model module in RETScreen software

Source: RETScreen ${ }^{\circledR}$ Software - own edited print screen.

During step one, in the Establish Baseline sub-module, the multiple regression analysis is performed. The sequence of activity is depicted in Figure 4.

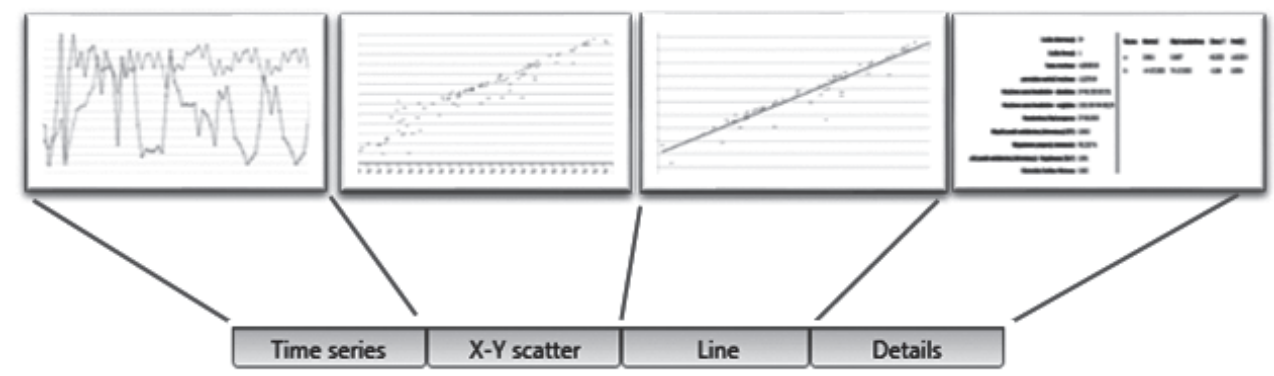

Fig. 4. The workflow in the Establish Baseline sub-module in RETScreen software

Source: RETScreen ${ }^{\circledR}$ Software - own edited print screen compilation. 
- In the first activity, Time series, the imported time series of the dependent and independent variables are collected in a chart and in a tabular format.

- In the second activity, $X-Y$ scatter, the values of the variables are shown in the $\mathbf{x}-\mathbf{y}$ relation, where $\mathbf{x}$ represents the independent variable values and $\mathbf{y}$ represents the dependent variable values (energy consumption).

- In the third activity, Line, the software determines the coefficients of a one or polynomial model that describes the correlation between the dependent variable $\mathrm{y}$ and the independent variables (for example $\mathrm{x}$ or $\mathrm{x}_{1}, \mathrm{x}_{2}$ ). The user can choose the type and degree of regression. In this step, a line representing the determined energy-use model is drawn.

- In the fourth activity, Details, one can review the analytical details of the model and the results of its statistical analysis, including the values of the multiple determination coefficient $\left(\mathrm{R}^{2}\right)$ and the value of the standard error of the estimate. This information is used in the model quality assessment process, giving values of two quantitative criteria.

The second step relates to the original purpose of the RETScreen. It enables the determination of the energy goal: the desired energy consumption planned as a result of the pro-efficiency activity, that is the subject of the analysis performed during the current session. KGHM does not use this functionality.

The third step is the plot of the CUSUM chart to assess the quality of the energy use model created in the first step. This operation is repeated until the reference period is identified, or until one can confirm that identifying this period is not feasible.

In the case of having a finite number of samples with specific characteristics, it happens that it is not feasible to identify the reference period, so it is not possible to build a reference energy use model. The inability to determine the energy baseline does not mean that no savings were reached in the analysed area - it only means that it cannot be determined reliably. This knowledge is also valuable because it becomes a source of recommendations that its exploitation will make possible to set savings in the future which are not possible now.

The successful identification of the reference period begins the last iteration of creating an energy-use model that takes place during the first step. The energy baseline is the set of values estimated by the reference model of energy use in the reporting period. The values are presented in a table and as a chart.

In the final step, the data specifying the amount of energy consumption predicted by the model are exported to MS Excel, calculating the energy savings achieved in the reporting period. The valuable management information is the graphical representation of the energy baseline, the energy consumption and energy saving, see Figure 5. 


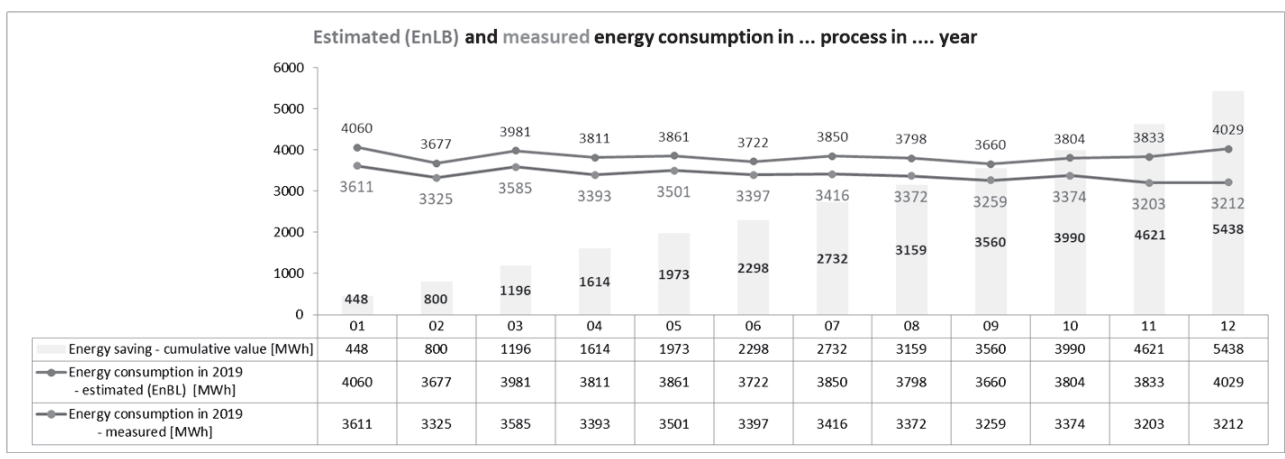

Fig. 5. Results of the analysis - reporting chart with energy baseline, energy consumption and cumulative energy saving

Source: MS Excel print screen - own work.

Energy saving is the result of comparing the actual energy consumption with the estimated energy consumption (energy baseline, EnB) and is defined as the sum of the differences between the EnB value and the actual consumption in each month.

As the energy-use model is created based on data from the reference period, the CUSUM chart can show the amount of energy saved in time after the reference period, including the period of changes in the assessed process and reporting period. It is important to note that the baseline period and reporting period for determining energy saving is the same. This situation is related to the definition of energy saving. The relation between periods and the way to visualise the energy savings are shown in Figure 6.

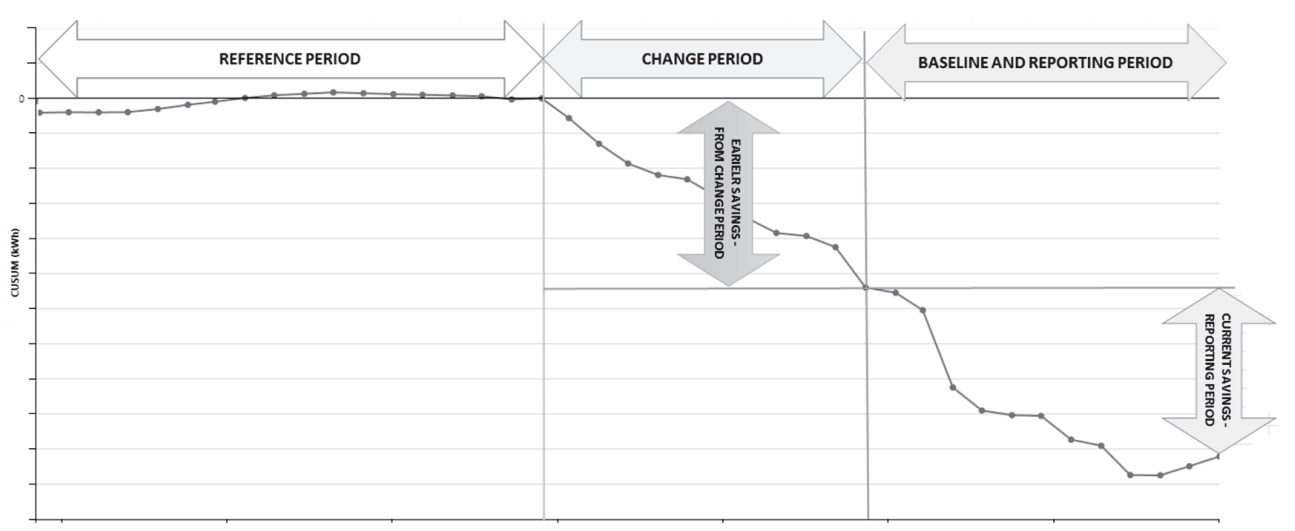

Fig. 6. CUSUM chart - relation with periods and cumulative energy saving Source: MS Excel print screen - own work. 


\section{Practical consideration}

When KGHM started the system approach to energy management, in particular the determination effects of the performed pro-efficiency actions, the effectiveness in this area was difficult to quantify. The methodology used was incompatible with the European regulations and standards, and its results were practically unusable. The results of the application of the described method, supported by the use of the presented software, indicate that about $80 \%$ of the analyses may be completed with the proper determination of savings with $80 \%$ probability. Usually, the standard error of estimation does not exceed $25 \%$ of the determined value of savings, but often it is less than that. The quality of determining energy savings is growing with the growing amount of data. The accuracy is also more remarkable when the disturbance in the process is lower. In about $20 \%$ of cases, where one could not determine the energy saving as a result of the analysis, one could identify the causes of analytical difficulties. This enables to provide recommendations for the elimination of these problems in the future.

The result of the analysis presented in the form of a chart allows top management to quickly assess the degree of improvement in the energy efficiency of the analysed process, naturally at the specified initial level of detail. Objectively verifiable knowledge enables a qualitative evaluation of the process, as opposed to attempts to make such an evaluation based on quantitative indicators. The correct following of scientific principles, defined savings, and information reflecting the actual state with a determinable accuracy and certainty, allow to make correct management decisions.

The limitations of the process are related to it being labour-intensive, especially at the stage of model quality assessment. The subject of future research may be a method of automating this stage, e.g. using artificial intelligence. Another limitation is access to valuable, from the modelling perspective, information about the factors influencing energy consumption (values of independent variables). This problem can be solved by implementing a measurement system aimed at collecting the needed information.

A further limitation is the character of the process - if it is disturbed, there is no way to determine a reference period and also the real savings. As the solution to this problem one could consider the identification of episodes causing the disturbance and exclusion of the related data from the analysis. Another solution can be the decomposition of the process to sub-processes, analysing and the evaluation of each independently - then the saving in the process will be the sum of the savings in the sub-processes. Furthermore, one could modify the data collection process, starting with increasing the frequency of measurements to the installation of new metering tools in the appropriate points, to increase the amount of data. All of these solutions are under consideration in KGHM. 
It is important to remember that energy saving is always the result of effectively conducted pro-efficiency measures. Energy saving may also be the result of changing conditions favourably influencing the characteristics of the process. Yet the evolution of these conditions cannot be the source of energy saving.

\section{Conclusion}

The developed approach shows a ready-to-use simple method and a commonly available tool to determine energy savings in complex business processes, efficiently and cheaply. The determined energy saving is compatible with science, international regulations and standards, hence it is easy to prove during the audit that it is carried out correctly. Finally, there is the valuable management information, which when appropriately used will lead to the improvement of energy efficiency and, as a result, reduced energy consumption.

\section{References}

Cheng, C.-L., Shalabh, and Garg, G. (2012). Coefficient of determination for multiple measurement error models. Journal of Multivariate Analysis, 126, 137-152. Retrieved from https://www.sciencedirect.com/science/article/pii/S0047259X14000141

Commission Recommendation (E.U.) 2019/1658 of 25 September 2019 on transposing the energy savings obligations under the Energy Efficiency Directive. (2019.09.25). Retrieved from https:// eur-lex.europa.eu/legal-content/AUTO/?uri=CELEX:32019H1658\&qid=1607415137439\&rid=1

Copenhagen Centre of Energy Efficiency [CCEE]. (2020). Introduction to RETScreen clean energy management software (Webinar). Retrieved from https://c2e2.unepdtu.org/kms_object/introduction-to-retscreen-clean-energy-management-software-webinar/

Cosenza, E., Devetta, M., Rošā, M., Žogla, L., Barisa, A., Toma, M., and Stiff, G. (2018). Energy Management System (EnMS) guidebook for local authorities. Retrieved from https://ec.europa.eu/ research/participants/documents/downloadPublic?documentIds $=080166 \mathrm{e} 5 \mathrm{bd} 36717 \mathrm{e} \& \mathrm{appId}=\mathrm{P}-$ PGMS

Directive 2006/32/EC of The European Parliament and of The Council of 5 April 2006 on energy end-use efficiency and energy services and repealing Council Directive 93/76/EEC. (2006.05.04). Retrieved from https://eur-lex.europa.eu/legal-content/EN/ALL/?uri=CELEX\%3A32006L0032

Directive 2012/27/E.U. of the European Parliament and of the Council of 25 October 2012 on energy efficiency, amending Directives 2009/125/E.C. and 2010/30/E.U. and repealing Directives 2004/8/ EC and 2006/32/E.C. (2012.10.25). Retrieved from https://eur-lex.europa.eu/legal-content/AUTO/?uri=CELEX:32012L0027\&qid=1607414070714\&rid=1

Directive (E.U.) 2018/2002 of the European Parliament and of the Council of 11 December 2018 amending Directive 2012/27/E.U. on energy efficiency. (2018.12.11). Retrieved from https://eur-lex. europa.eu/legal-content/AUTO/?uri=CELEX:32018L2002\&qid=1607413459409\&rid=1

European Commission. (2015). Communication from the Commission To The European Parliament, The Council, The European Economic and Social Committee, The Committee of the Regions And The European Investment Bank a Framework Strategy for a Resilient Energy Union with a Forward-Looking Climate Change Policy. Retrieved from https://eur-lex.europa.eu/legal-content/ AUTO/?uri=CELEX:52015DC0080\&qid=1607412972373\&rid=1 
Eurostat. (2020). Energy production and imports. Retrieved from https://ec.europa.eu/eurostat/statistics-explained/index.php/Energy_production_and_imports

Farkas, K. (2016). CUSUM Anomaly Detection. Measurement Lab. Retrieved from https://www.measurementlab.net/publications/CUSUMAnomalyDetection.pdf

Federal Ministry for the Environment, Nature Conservation and Nuclear Safety (BMU). (2012). Energy management systems in practice ISO 50001: A guide for companies and organisations. Retrieved from https://www.academia.edu/38430525/Kupdf net iso 50001 manual bmupdf

Government of Canada [GoC]. (2020). RETScreen. Retrieved from https://www.nrcan.gc.ca/maps-tools-publications/tools/data-analysis-software-modelling/retscreen/7465

Greber, T. (2005). Statystyczne sterowanie procesami - praktyczne przykłady zastosowania. Politechnika Wroctawska. Zarzązanie jakością. Retrieved from https://media.statsoft.pl/_old_dnn/downloads/statystyczne_sterowanie_procesami.pdf

Howell, M. T. (2014). Effective implementation of an ISO 50001 Energy Management System (EnMS). Wisconsin: ASQ Quality Press Milwaukee,. Retrieved from https://www.academia. edu/32600564/_EnMS_Marvin_T_Howell_Effective_implementation_of_an_ISO_50001_energy_management_system_EnMS_ASQ_Quality_Press_2014

International Performance Measurement and Verification Protocol. [IPMVP]. (2012). Concepts and Options for Determining Energy and Water Savings. Efficiency Valuation Organisation. Retrieved from www.evo-world.org

ISO/IEC 13273-1. (2015.06.01). Energy efficiency and renewable energy sources - Common international terminology - Part 1: Energy efficiency.

ISO 17741. (2016.05.01). General technical rules for measurement, calculation and verification of energy savings of projects.

ISO 17743. (2016.06.01). Energy savings - Definition of a methodological framework applicable to calculation and reporting on energy savings.

ISO 50001. (2018). Energy management systems - Requirements with guidance for use.

ISO 50046. (2019). General methods for predicting energy savings.

Komisja Europejska, Przedsiębiorstwa i przemysł [KEPip]. (2011). Efektywne wykorzystanie energii $w$ firmie - poradnik dla przedsiębiorców. Retrieved from https://poig.parp.gov.pl/ files/74/81/469/12706.pdf

Koshti, V. V. (2011). Cumulative sum control chart. International Journal of Physics and Mathematical Sciences. 1(1), 28-32. Retrieved from https://www.researchgate.net/publication/230888065_Cumulative_sum_control_chart

Lin, J., Keogh, E. J., and Lonardi, S. (2005). Visualising and discovering non-trivial patterns in large time series databases. Information Visualization, 4(2), 61-82. Retrieved from https://www.researchgate.net/publication/220586534_Visualizing_and_Discovering_Non-Trivial_Patterns_in_Large_Time_Series_Databases

Lycken, A., Nilsson, D., Olsson, M., Diederichs, S., Welling, J., and Guennec, T. (2015). SawEnMS handbook. Retrieved from http://www.ecoinflow.com/Portals/0/SawEnMS_handbook_final_ EN\%20print_compressed_web.pdf

Natural Resources Canada [NRC]. (2005). RETScreen ${ }^{\circledR}$ software online user manual. Retrieved from https://unfccc.int/resource/cd_roms/na1/mitigation/Module_5/Module_5_1/b_tools/RETScreen/ Manuals/Ground_Source_Heat_Pumps.pdf

Open Energy Information [OpenEI]. (2020). RETScreen clean energy project analysis software. Retrieved from https://openei.org/wiki/RETScreen_Clean_Energy_Project_Analysis_Software

Syska, J. (2014). Wspótczesne metody analizy regresji wspomagane komputerowo - Skrypt dla studentów Ekonofizyki. Katowice: Instytut Fizyki, Uniwersytet Śląski. Retrieved from https://el.us.edu. $\mathrm{pl} /$ ekonofizyka/images/b/b6/MetodyDoboruModeli.pdf

Świecicki, J., and Tautkut e, I. (2012). Wybrane statystyczne metody wykrywania stanów alarmowych 
na przykladzie danych o zachorowaniach na grypę w Polsce (praca licencjacka na kierunku Matematyka). Uniwersytet Warszawski. Retrieved from http://matrix.umcs.lublin.pl/ akrajka/SEMINARIUM/R\%20Epidemiology/JakubSwiecickiIvonaTautkute.pdf

United Nations Industrial Development Organization [UNIDO]. (2015). Practical guide for implementing an energy management system. Retrieved from https://www.industrialenergyaccelerator.org/ wp-content/uploads/IEE_EnMS-Practical-Guide.pdf

Ustawa z dnia 20 maja 2016 r. o efektywności energetycznej (Dz. U. 2016, poz. 831). Retrieved from https://isap.sejm.gov.pl/isap.nsf/DocDetails.xsp?id=WDU20160000831 